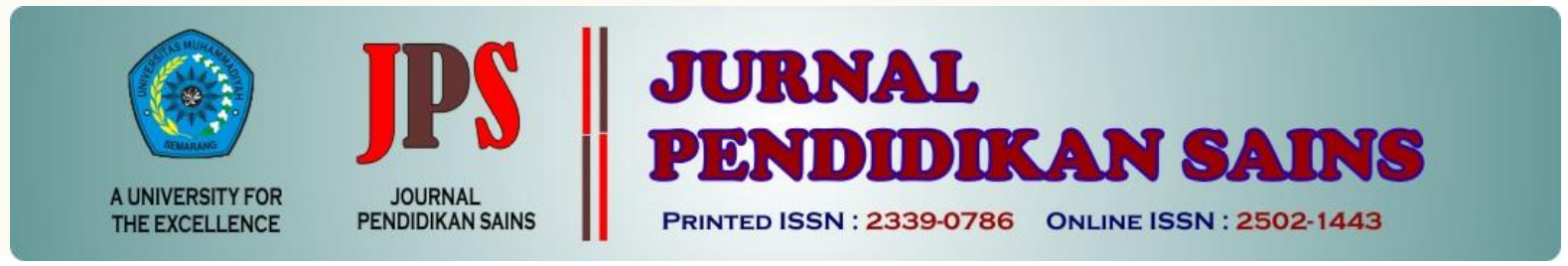

http://jurnal.unimus.ac.id/index.php/JPKIMIA

\title{
PENILAIAN KUALITAS MEDIA AUDIO VISUAL TENTANG KARAKTERISTIK LARUTAN ASAM BASA UNTUK SISWA SMA/MA
}

\author{
Oleh: Nokman Riyanto ${ }^{1}$ dan Anjar Purba Asmara ${ }^{2}$ \\ ${ }^{1}$ SMP Negeri 2 Bojongsari Purbalingga \\ ${ }^{2}$ Prodi Kimia FST UIN Ar-Raniry Banda Aceh
}

\begin{tabular}{ll}
\hline \multicolumn{2}{l}{ Article history } \\
\hline Submission & $: 2018-02-24$ \\
Revised & $: 2018-03-02$ \\
Accepted & $:$ 2018-03-08
\end{tabular}

Keyword:

Kata kunci: media audio visual, larutan asam basa, pH larutan, pembelajaran kimia, SMA/MA

\begin{abstract}
Penelitian ini merupakan penelitian research and development (R\&D) yang bertujuan untuk mengembangkan media audio visual tentang karakteristik larutan asam basa dan menentukan kualitas media tersebut. Pengembangan media audio visualnya menggunakan model prosedural dari Allesi \& Trollip (2001) yang melibatkan evaluasi dari ahli media dan peer reviewer masing-masing sebanyak tiga orang. Penentuan kualitas medianya menggunakan analisis deskriptif kuantitatif melalui penilaian oleh lima orang guru kimia SMA sebagai reviewer menggunakan rubrik analitik yang mengadaptasi model Mertler (2001). Rubrik yang dikembangkan memiliki delapan aspek yang dijabarkan menjadi tiga puluh enam kriteria penilaian dengan skala 5. Media yang dihasilkan mengangkat dua topik, yaitu penentuan sifat larutan dan penentuan $\mathrm{pH}$ suatu larutan, yang dikemas dalam file dengan format .exe. Skor rerata total hasil penilaian kualitas sebesar 130,80 dan persentase keidealan sebesar 72,67 \% yang mengindikasikan bahwa media hasil penelitian ini berkualitas baik. Media ini baik untuk pembelajaran karena isi materinya valid, penggunaan bahasa yang komunikatif, praktis dan mudah digunakan, tampilan audio dan visualnya menarik, serta mengandung komponen evaluasi pembelajaran. Penelitian ini merekomendasikan untuk melanjutkan riset sejenis yang inovatif agar dapat meningkatkan keterampilan proses siswa sehingga diperoleh media audio visual yang kualitasnya lebih baik lagi.
\end{abstract}

\section{A. Pendahuluan}

Ilmu kimia merupakan salah satu dari rumpun IPA yang memiliki karakteristik saintifik dan empirik. Ilmu kimia lahir dari kegiatan eksperimental di laboratorium yang direpresentasikan dalam tiga tingkatan, yaitu mikroskopik, simbolik, dan makroskopik (Wu,
Krajcik, \& Soloway, 2000). Riset dari Ben-Zvi, Eylon, \& Silberstein (1987) menunjukkan bahwa siswa mengalami kesulitan mempelajari kimia di tingkat mikroskopis dan simbol karena keduanya tak kasat mata dan abstrak (Urbanger \& Kometz, 2014).

Salah satu materi pembelajaran inti dalam kimia adalah larutan asam basa. Menurut

*Corresponding Author:

$\begin{array}{ll}\text { Nama } & \text { : Anjar Purba Asmara } \\ \text { Lembaga } & \text { : Prodi Kimia FST UIN Ar-Raniry } \\ \text { Email } & \text { : anjarpa@ar-raniry.ac.id }\end{array}$


Childs \& Sheehan (2007), materi larutan asam basa tergolong dalam sepuluh besar topik pembelajaran kimia yang dianggap sulit oleh siswa dengan persentase sebesar 37\%. Faktor mendasar yang menyebabkannya adalah pemahaman materi larutan asam basa membutuhkan integrasi antara pemikiran skala makro dari pengamatan terhadap karakteristik fisik keasaman suatu larutan dengan pemikiran skala mikro tentang pengaruh ion $\mathrm{H}^{+}$dan skala simbolik yang dinyatakan dalam harga $\mathrm{pH}$ (Johnstone, 2006). Hal ini menyebabkan siswa terbebani sementara alokasi waktu pembelajarannya terbatas sehingga kurang menguasai materi ini dan melahirkan miskonsepsi (Nakhiekh, 1992).

Salah satu cara untuk meningkatkan pemahaman siswa dalam pembelajaran kimia adalah penggunaan media pembelajaran yang praktis dan muatan isi pembelajarannya valid (Urbanger \& Kometz, 2014). Usaha untuk meningkatkan kebermaknaan suatu media dapat dilakukan melalui penggunaan media digital yang dapat dioperasikan pada sistem berbasis Windows maupun Android yang telah melalui proses verifikasi kualitas isi dan tampilannya (Urbanger \& Kometz, 2014). Media audio visual sangat tepat untuk diterapkan pada sarana berbasis digital namun kendali kandungan isi dan tampilannya perlu dilakukan melalui riset yang melibatkan guru.

Media audio visual merupakan alat pembelajaran yang menampilkan kesan suara dan gambar sekaligus dalam satu kali putar melalui berbagai wahana aplikasi berbasis digital (Ashaver \& Igyuve, 2013). Menurut Swank (2011), keefektifan pembelajaran sebesar $40 \%$ diperoleh siswa dari pengalaman visual, $25 \%$ dari auditori, $17 \%$ dari perabaan, $15 \%$ dari berbagai sensasi organik lainnya dan $3 \%$ dari sensasi aroma.

Penggunaan video dalam pembelajaran kimia terbukti berhasil dalam menyelesaikan permasalahan (seperti kesulitan memahami konsep, miskonsepsi, dan kurangnya motivasi) yang tidak terselesaikan dengan metode tradisional (Blonder et al., 2013). Burewicz dan Miranowicz. (2006) menyebutkan bahwa audio visual juga mampu mengurangi kesalahan siswa dalam memahami konsep dalam kegiatan praktikum. Hal ini menegaskan bahwa media audio visual sangat penting untuk mencapai keberhasilan pembelajaran karena mampu menampilkan model dan simulasi materi berukuran mikroskopik (Cheng, 2017). Media ini sangat tepat untuk mengurangi kesulitan belajar siswa pada subjek-subjek abstrak seperti kimia.

Media audio visual yang baik membutuhkan desain visualisasi dan bobot materi yang baik pula untuk membantu siswa menguasai ketiga tingkatan kajian ilmiah kimia tersebut dan belajar secara mandiri. Namun hingga saat ini, banyak animasi dan simulasi berbasis digital tentang fenomena kimiawi tanpa susunan yang sistematis tentang pengenalan konsep dasar dan tidak memperhatikan potensi miskonsepsi dari siswa setelah melihat video tersebut (Akaygun \& Jones, 2013). Untuk mendapatkan media yang yang baik, rancangan pengembangannya didesain dengan model baku. Produknya harus diujikan kepada ahli media dan guru untuk proses verifikasi isi sebelum diberikan kepada siswa (Akaygun dan Jones, 2013).

Berdasarkan latar belakang tersebut, kajian pengembangan media audio visual pada pembelajaran kimia materi asam basa diperlukan untuk menghasilkan media pembelajaran yang efektif. Hal penting yang diangkat dalam penelitian ini adalah bagaimana mendesain, mengembangkan, dan menilai kualitas media audio visual berdasarkan strategi desain media berdasarkan Tversky et al. (2006) yang menenkankan bahwa media harus diujikan ke ahli media dan guru sebelum diberikan kepada siswa. Media audio visual yang dikembangkan dan dinilai kualitasnya dalam penelitian ini menampilkan video demonstrasi atau praktikum yang terkait dengan sifat-sifat keasaman suatu larutan dan $\mathrm{pH}$ suatu larutan yang bersifat abstrak bagi siswa pada umumnya.

\section{B. Metode Penelitian}

\section{Jenis Penelitian}

Penelitian ini merupakan penelitian pengembangan (Research and Development) yang bertujuan untuk menghasilkan dan menilai kualitas produk tersebut (Sugiyono, 2009). Penelitian ini menggunakan model pengembangan yang dijadikan dasar untuk mengembangkan produk penelitian. Model pengembangan yang digunakan adalah model prosedural yang terdiri dari dua tahap, yaitu tahap pengembangan media audio visual dan tahap penilaian media (Sugiyono, 2009).

Penelitian ini merupakan penelitian deskriptif kuantitatif yang bertujuan menghimpun data kuantitatif dan menjelaskannya secara kualitatif. Kualitas suatu produk penelitian dinyatakan dalam bentuk 
angka/data kuantitatif. Data tersebut dihimpun dari penilaian kualitas media oleh 5 orang guru kimia SMA.

Data yang diperoleh selanjutnya dianalisis secara statistik dan diinterpetasikan kembali ke dalam informasi kualitatif. Informasi yang diperoleh digunakan untuk menguji, memberikan penguatan/konfirmasi, atau membantah teori yang sudah ada dan membangun teori baru (Thomas, 2010).

\section{Waktu dan Tempat Penelitian}

Pengembangan media audio visual dilaksanakan di Yogyakarta pada tahun 2017 Analisis data hasil penelitian dilaksanakan pada Desember 2017 - Februari 2018.

\section{Subjek Penelitian}

Subjek penelitian ini tim validator media yang terdiri dati tiga orang peer reviewer dan tiga orang ahli media serta tim penilai kualitas media yang terdiri dari lima orang reviewer. Objek penelitian ini adalah media audio visual dalam bentuk software dengan format, exe yang dapat diputar di semua sistem operasi digital.

Pemilihan ketiga jenis responden ini sesuai dengan metode triangulasi yang digunakan oleh Thomas (2010). Untuk menghindari penyimpangan (bias) isi materi dan memastikan keabsahan (validity) dari produk riset $\mathrm{R} \& \mathrm{D}$, produk penelitian harus diperiksa oleh tiga macam penguji. Penentuan peer reviewer dan ahli media dilakukan berdasarkan pertimbangan profesi dan reputasinya. Penentuan reviewer sebanyak 5 orang guru kimia SMA di Kota Yogyakarta ditentukan berdasarkan peringkat sekolah berdasarkan nilai Ujian Nasional mata pelajaran kimia (peringkat atas dan bawah masingmasing diambil satu guru dan peringkat sedang diambil tiga guru).

\section{Prosedur}

Prosedur pengembangan dalam penelitian ini menggunakan model Allesi \& Trollip (2001) yang dikembangkan oleh Asmara (2015). Tahap-tahap dalam model ini meliputi:

a) Tahap perencanaan meliputi perumusan tujuan dan mengidentifikasi kebutuhan; penyiapan sumber referensi materi; dan perancanan isi dan tampilan media.

b) Tahap desain media meliputi perancangan skenario dan instrumen pendukung lainnya yang berisi narasi naskah verbal, dan deskripsi materi serta soal-soal latihan; pembuatan storyboard; selanjutnya adalah pengambilan gambar, video rendering dari kamera ke komputer, dan video editing; pembuatan flowchart untuk mengoperasikan program Macromedia Flash 8.0.

c) Tahap pengembangan meliputi penyiapan template untuk penempatan komponen isi media dalam house program Macromedia Flash 8.0.; ekspor file video ke dalam house program lalu dirangkai dengan animasi dan materi pembelajaran; produksi media dalam format exe yang dapat diputar baik di sistem personal computer maupun sistem berbasis Android; dan evaluasi serta validasi media oleh ahli media dan peer reviewer.

d) Penilaian produk menggunakan desain deskriptif dengan tahap-tahap seperti dalam Gambar 1 (Coughian, Cronin, dan Ryan, 2007).

\section{Data, Instrumen, dan Teknik Pengumpulan Data}

Data yang digunakan adalah data kualitatif dan data kuantitatif. Data kualitatif digunakan untuk mengetahui kualitas media menggunakan skala Likert dengan kategori sangat baik (SB), baik (B), cukup (C), kurang (K), sangat kurang (SK) (Morgil et al., 2007 dan Asmara, 2015). Data tersebut diperoleh dengan rubrik analitik model Mertler (2001) yang terdiri dari 8 aspek penilaian dengan 36 kriteria penilaian. Rubrik diisi oleh guru dengan memilih salah satu jawaban yang telah disediakan melalui check list (Calder, 2008). Aspek yang dinilai adalah:

$\mathrm{A}=$ kebenaran, keluasan, dan kedalaman konsep

$\mathrm{B}=$ kebahasaan yang digunakan

$\mathrm{C}=$ keterlaksanaan

$\mathrm{D}=$ tampilan visual/gambar

$\mathrm{E}=$ tampilan audio/suara

$\mathrm{F}=$ kemudahan penggunaan

$\mathrm{G}=$ kegiatan siswa

$\mathrm{H}=$ evaluasi belajar

Data kuantitatif berupa data diskrit (nominal) yang diperoleh dengan cara menghitung rata-rata skor tiap kriteria berdasarkan penilaian reviewer. Selanjutnya skor dari reviewer dibandingkan dengan skor ideal untuk mengetahui kualitas media audio visual yang dihasilkan. 


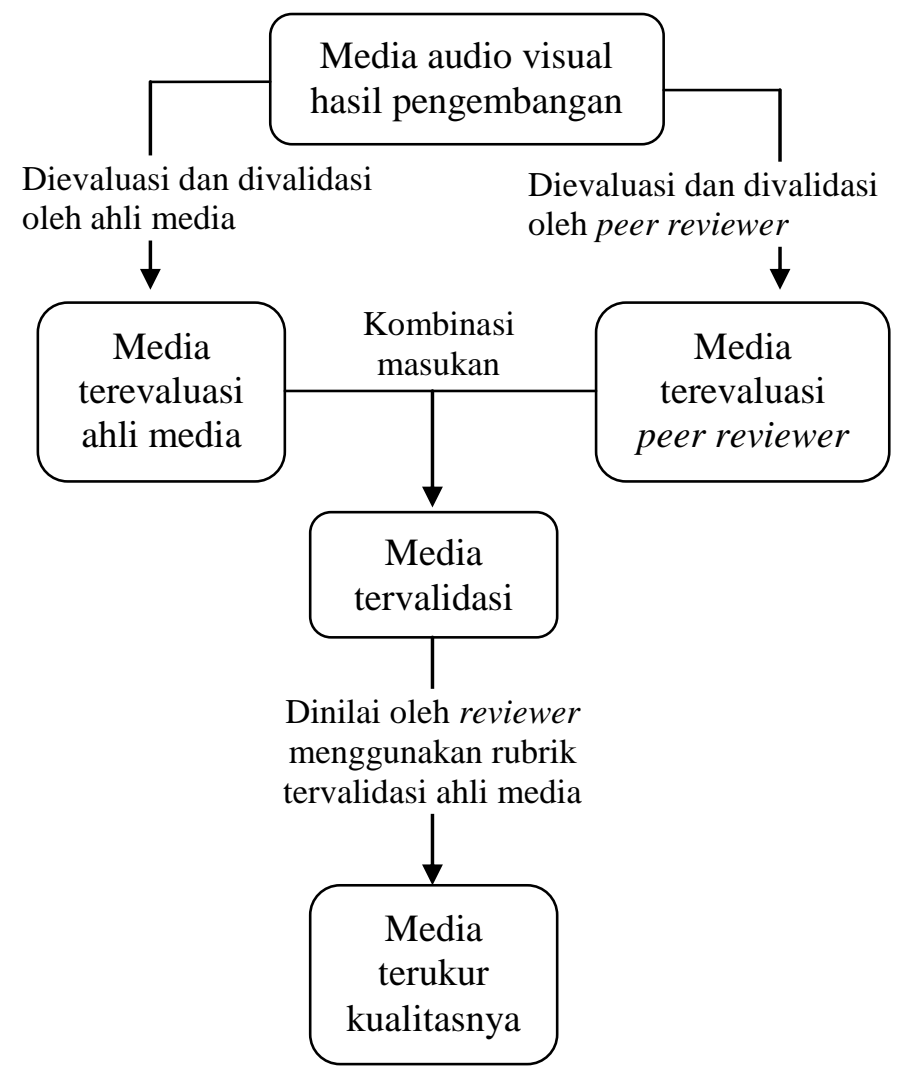

Gambar 1. Skema penilaian produk penelitian hasil pengembangan

\section{Teknik Analisis Data}

Data dianalisis secara deskriptif dengan langkah-langkah sebagai berikut:

a) Reviewer memberikan skor penilaian kualitas media tiap aspek pada rubrik yang diberikan mengikuti aturan yang disajikan pada Tabel 1.

Tabel 1. Aturan Pemberian Skor

\begin{tabular}{|l|c|}
\hline \multicolumn{1}{|c|}{ Kategori } & Skor \\
\hline SK (Sangat Kurang) & 1 \\
\hline K ( kurang ) & 2 \\
\hline C ( cukup ) & 3 \\
\hline B ( baik ) & 4 \\
\hline SB (sangat baik ) & 5 \\
\hline
\end{tabular}

b) Menghitung skor rata-rata setiap aspek yang dinilai lalu mengubahnya menjadi nilai kualitatif sesuai dengan kriteria kategori penilaian yang dijabarkan dalam Tabel 2 berikut ini:

Tabel 2. Kriteria Kategori Penilaian ideal

(Arikunto, 2002)

\begin{tabular}{|c|c|c|}
\hline No & Rentang Skor (i) & Kategori \\
\hline 1 & $\overline{\mathrm{X}}>\mathrm{M}_{\mathrm{i}}+1,5 \mathrm{SDi}$ & Sangat \\
\hline
\end{tabular}

\begin{tabular}{|c|c|c|}
\hline No & Rentang Skor (i) & Kategori \\
\hline & \multicolumn{1}{|c|}{ Baik } \\
\hline 2 & $\begin{array}{l}\mathrm{M}_{\mathrm{i}}+0,5 \mathrm{SDi}<\overline{\mathrm{X}} \leq \mathrm{M}_{\mathrm{i}} \\
+1,5 \mathrm{SDi}\end{array}$ & Baik \\
\hline 3 & $\begin{array}{l}\mathrm{M}_{\mathrm{i}}-0,5 \mathrm{SDi}<\overline{\mathrm{X}} \leq \mathrm{M}_{\mathrm{i}} \\
+0,5 \mathrm{SDi}\end{array}$ & Cukup \\
\hline 4 & $\begin{array}{l}\mathrm{M}_{\mathrm{i}}-1,5 \mathrm{SDi}<\overline{\mathrm{X}} \leq \mathrm{M}_{\mathrm{i}}- \\
0,5 \mathrm{SDi}\end{array}$ & Kurang \\
\hline 5 & $\overline{\mathrm{X}} \leq \mathrm{M}_{\mathrm{i}}-1,5 \mathrm{SDi}$ & $\begin{array}{l}\text { Sangat } \\
\text { Kurang }\end{array}$ \\
\hline
\end{tabular}

Rerata ideal (Mi), simpangan deviasi (SDi), dan skor ideal diperoleh dengan rumus :

$\mathrm{Mi}=0,5$ (skor tertinggi + skor terendah)

$\mathrm{SDi}=0,167$ (skor tertinggi - skor terendah)

Skor ideal $=\mathrm{M}_{\mathrm{i}}+1,5 \mathrm{SDi}$

\section{Hasil Penelitian dan Pembahasan}

Hasil pengembangan ini yang pertama adalah media audio visual larutan asam basa dalam bentuk software pembelajaran dengan tipe format .exe. Berdasarkan klasifikasi media audio visual dari Ashaver dan Igyuve (2013), produk penelitian ini tergolong media audio visual tipe models, mock-ups globes, dan relief maps (kategori Realia) karena medianya menampilkan guru sebagai aktor yang memerankan model dalam demonstrasi praktikum asam basa. Berdasarkan kategori Aina-Olutade, media ini tergolong $16 \mathrm{~mm}$ cinematograph karena media menampilkan video bersuara yang memberikan gambaran nyata kerja di laboratorium dengan skenario sistematis.

Media audio visual ini terdiri dari dua topik bahasan yaitu penentuan sifat keasaman suatu larutan dan penentuan $\mathrm{pH}$ suatu larutan. Komponen lain di dalamnya antara lain standar kompetensi dan kompetensi dasar, petunjuk penggunaan media audio visual, lembar kegiatan siswa, lembar kerja siswa, kunci lembar kerja siswa, lembar evaluasi, kunci lembar evaluasi, tampilan peralatan laboratorium, sekilas info tentang materi asam basa. Produk penelitian ini memenuhi dwi fungsi media pembelajaran yaitu sebagai media pembelajaran di kelas dan jugs dapat digunakan sebagai sumber belajar mandiri siswa dimanapun dan kapanpun mereka berada (Fry, Ketteridge, \& Marshall, 2009). 


\section{Kualitas media audio visual tentang penentuan pH suatu larutan}

Video demonstrasi yang pertama ini memperoleh skor total rata-rata sebesar 130,8 dengan kualitas baik berdasarkan penilaian lima orang guru kimia SMA di Kota Yogyakarta. Skor rata-rata ideal yang dicapai sebesar 180 . Sehingga skor yang diperoleh jika dinyatakan dalam persentase keidealan adalah $72,67 \%$. Sedangkan data skor rata-rata penilaian kualitas media audio visual tentang penentuan sifat suatu larutan dapat dilihat pada Tabel 3 dan Gambar 2.

Tabel 3. Skor tiap aspek penilaian media audio visual tentang penentuan sifat suatu larutan

\begin{tabular}{|c|c|c|c|}
\hline Aspek & $\begin{array}{c}\text { Skor } \\
\text { rerata }\end{array}$ & $\begin{array}{c}\text { Skor } \\
\text { reata } \\
\text { Ideal }\end{array}$ & $\begin{array}{c}\text { Persentase } \\
\text { keidealan } \\
(\mathbf{\%})\end{array}$ \\
\hline A & 22,6 & 30 & 75,33 \\
\hline B & 12,2 & 15 & 81,33 \\
\hline C & 20,8 & 30 & 69,33 \\
\hline D & 21,6 & 30 & 72,00 \\
\hline E & 18,2 & 25 & 72,80 \\
\hline F & 6,8 & 10 & 68,00 \\
\hline G & 11,4 & 15 & 76,00 \\
\hline H & 17,2 & 25 & 68,80 \\
\hline
\end{tabular}

\begin{tabular}{|c|c|c|c|}
\hline Aspek & $\begin{array}{c}\text { Skor } \\
\text { rerata }\end{array}$ & $\begin{array}{c}\text { Skor } \\
\text { reata } \\
\text { Ideal }\end{array}$ & $\begin{array}{c}\text { Persentase } \\
\text { keidealan } \\
(\boldsymbol{\%})\end{array}$ \\
\hline Jumlah & 130,80 & 180 & 72,67 \\
\hline
\end{tabular}

Aspek kebenaran, keluasan, dan kedalaman konsep (aspek A) ini dijabarkan menjadi 6 kriteria. Aspek tersebut memperoleh skor rata-rata sebesar 22,6 dengan kualitas baik, sedangkan skor rata-rata ideal yang diharapkan tercapai sebesar 30. Jumlah skor masingmasing kriteria pada aspek ini dapat dilihat pada Tabel 4.

Tabel 4. Jumlah skor kriteria media audio visual untuk aspek A tentang penentuan sifat suatu larutan

\begin{tabular}{|c|c|c|}
\hline Kriteria & $\begin{array}{c}\sum \text { skor tiap } \\
\text { kriteria }\end{array}$ & Persentase kualitas \\
\hline 1 & 19,00 & 76,00 \\
\hline 2 & 18,00 & 72,00 \\
\hline 3 & 20,00 & 80,00 \\
\hline 4 & 19,00 & 76,00 \\
\hline 5 & 18,00 & 72,00 \\
\hline 6 & 19,00 & 76,00 \\
\hline
\end{tabular}

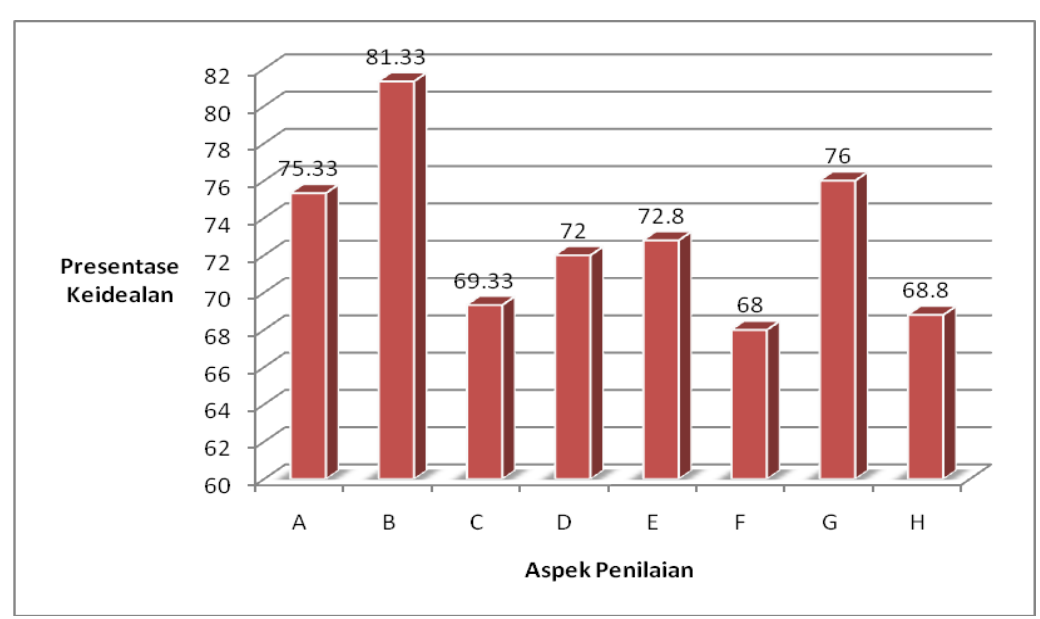

Gambar 2. Grafik skor tiap aspek penilaian media audio visual tentang penentuan sifat suatu larutan

Berdasarkan Tabel 4, kriteria (3) yaitu kesesuaian materi dengan standar kompetensi dan kompetensi dasar dinilai paling tinggi oleh reviewer, hal ini karena dalam media audio visual tentang larutan asam basa ini memenuhi standar kompetensi maupun kompetensi dasar dimana media ini dapat memberikan pengalaman kerja di laboratorium walaupun tidak secara langsung. Namun untuk kriteria (2) dan (5), nilainya lebih rendah karena kemungkinan media ini belum sistematis dalam penyampaian materi praktikumnya serta belum proporsionalnya materi esensial (identifikasi sifat larutan berdasarkan ciri fisik) dengan materi penunjangnya (contoh pemanfaatan sifat larutan untuk kehidupan). 
Aspek B yaitu aspek kebahasaan dijabarkan menjadi 3 kriteria yang memperoleh skor rata-rata sebesar 12,2 dengan kualitas sangat baik sedangkan skor rata-rata ideal yang diharapkan tercapai sebesar 15. Jumlah skor masing-masing kriteria pada aspek kebahasaan yang digunakan ini dapat dilihat pada Tabel 5 .

Tabel 5. Jumlah skor kriteria media audio visual aspek B tentang penentuan sifat suatu larutan

\begin{tabular}{|c|c|c|}
\hline Kriteria & $\begin{array}{c}\text { } \begin{array}{c}\text { skor tiap } \\
\text { kriteria }\end{array} \\
\text { Persentase } \\
\text { kualitas }\end{array}$ \\
\hline 1 & 20,00 & 80,00 \\
\hline 2 & 20,00 & 80,00 \\
\hline 3 & 21,00 & 84,00 \\
\hline
\end{tabular}

Berdasarkan Tabel 5, kriteria (3) yaitu penggunaan bahasa yang mudah dipahami atau komunikatif dinilai lebih tinggi oleh reviewer, hal ini karena dalam media audio visual ini telah menggunakan bahasa yang komunikatif. Namun untuk kriteria (1) penggunaan bahasa yang baku dan kriteria (2) penggunaan bahasa yang tidak menimbulkan penafsiran ganda dinilai lebih rendah karena ada beberapa katakata yang digunakan dalam media ini yang tidak baku dan ambiguisitasnya relatif besar.

Aspek C, yaitu keterlaksanaan, dijabarkan menjadi 6 kriteria. Aspek yang ketiga ini memperoleh skor rata-rata sebesar 20,8 dengan kualitas baik sedangkan skor ratarata ideal yang diharapkan tercapai sebesar 30 . Jumlah skor masing-masing kriteria pada aspek ketiga ini dapat dilihat pada Tabel 6.

Tabel 6. Jumlah skor kriteria media audio visual untuk aspek $\mathrm{C}$ tentang Penentuan Sifat Suatu Larutan

\begin{tabular}{|c|c|c|}
\hline Kriteria & $\begin{array}{c}\sum \text { skor tiap } \\
\text { kriteria }\end{array}$ & Persentase kualitas \\
\hline 1 & 19,00 & 76,00 \\
\hline 2 & 17,00 & 68,00 \\
\hline 3 & 17,00 & 68,00 \\
\hline 4 & 17,00 & 68,00 \\
\hline 5 & 18,00 & 72,00 \\
\hline 6 & 16,00 & 64,00 \\
\hline
\end{tabular}

Berdasarkan Tabel 6, kriteria (1) yaitu kesesuaian dengan kompetensi dasar dinilai lebih tinggi oleh reviewer karena media ini sudah sesuai dengan kompetensi dasar dimana media ini dapat memberikan pengalaman kerja di laboratorium. Namun untuk kriteria (6) yaitu penyajian materi secara menarik dinilai lebih rendah dalam aspek ini, hal ini karena media audio visual tentang praktikum asam basa ini ada bagian yang belum begitu menarik dalam penyampaian materi praktikumnya.

Aspek D yaitu aspek tampilan yang dijabarkan menjadi 6 kriteria. Aspek yang keempat ini memperoleh skor rata-rata sebesar 21,6 dengan kualitas baik sedangkan skor ratarata ideal yang diharapkan tercapai sebesar 30 . Jumlah skor masing-masing kriteria pada aspek keempat ini dapat dilihat pada Tabel 7.

Tabel 7. Jumlah skor kriteria media audio visual aspek D tentang penentuan sifat suatu larutan

\begin{tabular}{|c|c|c|}
\hline Kriteria & $\begin{array}{c}\text { E skor tiap } \\
\text { kriteria }\end{array}$ & $\begin{array}{c}\text { Persentase } \\
\text { kualitas }\end{array}$ \\
\hline 1 & 18,00 & 72,00 \\
\hline 2 & 17,00 & 68,00 \\
\hline 3 & 19,00 & 76,00 \\
\hline 4 & 17,00 & 68,00 \\
\hline 5 & 18,00 & 72,00 \\
\hline 6 & 19,00 & 76,00 \\
\hline
\end{tabular}

Berdasarkan Tabel 7, kriteria (3) yaitu ukuran huruf dan kriteria (6) yaitu ketepatan letak sudut pengambilan gambar dinilai lebih tinggi oleh reviewer karena pengaturan ukuran huruf dalam video tersebut dilakukan secara proporsional serta pengambilan sudut pandang pengambilan gambar ada di depan praktikan langsung. Namun untuk kriteria (2) yaitu warna gambar yang jelas dan terang dan (4) yaitu tingkat interaktivitas dinilai lebih rendah dalam aspek ini karena proses pengambilan gambar dilakukan tanpa pencahayaan yang cukup terang serta belum optimal dalam segi tingkat interaktivitasnya.

Aspek E yaitu aspek tampilan suara yang dijabarkan menjadi 5 kriteria. Aspek yang kelima ini memperoleh skor rata-rata sebesar 18,2 dengan kualitas naik sedangkan skor ratarata ideal yang diharapkan tercapai sebesar 25 . Jumlah skor masing-masing kriteria pada aspek kelima ini dapat dilihat pada Tabel 8 .

Tabel 8. Jumlah skor kriteria media audio visual aspek $\mathrm{E}$ tentang penentuan sifat suatu larutan

\begin{tabular}{|c|c|c|}
\hline Kriteria & $\begin{array}{c}\sum \text { skor tiap } \\
\text { kriteria }\end{array}$ & $\begin{array}{c}\text { Persentase } \\
\text { kualitas }\end{array}$ \\
\hline 1 & 17,00 & 68,00 \\
\hline 2 & 19,00 & 76,00 \\
\hline 3 & 18,00 & 72,00 \\
\hline
\end{tabular}




\begin{tabular}{|c|c|c|}
\hline Kriteria & $\begin{array}{c}\text { N skor tiap } \\
\text { kriteria }\end{array}$ & $\begin{array}{c}\text { Persentase } \\
\text { kualitas }\end{array}$ \\
\hline 4 & 18,00 & 72,00 \\
\hline 5 & 19,00 & 76,00 \\
\hline
\end{tabular}

Berdasarkan Tabel 8, kriteria (2) kejelasan vokal dan kriteria (5) yaitu intonasi suara pada hal-hal yang penting dinilai lebih tinggi oleh reviewer karena dalam media audio ini sudah diperkirakan sejauh mana vokal yang bisa diakses oleh kamera dengan jelas sehingga vokalnya mendapat hasil yang jelas serta penekanan intonasi pada hal-hal yang dianggap penting guna memberikan dorongan untuk penyimpulan dalam segi audionya. Namun untuk kriteria (1) yaitu volume suara dinilai paling rendah dalam aspek ini karena dalam proses pengeditan video media audio visual tentang praktikum asam basa ini ada pengurangan volume guna mengurangi vibrasi suara dari luar.

Aspek F yaitu aspek kemudahan penggunaan dijabarkan menjadi 2 kriteria. Aspek yang keenam ini memperoleh skor ratarata sebesar 6,8 dengan kualitas baik sedangkan skor rata-rata ideal yang diharapkan tercapai sebesar 10. Jumlah skor masing-masing kriteria pada aspek keenam ini dapat dilihat pada Tabel 9.

Tabel 9. Jumlah skor kriteria media audio visual untuk aspek $\mathrm{F}$ tentang penentuan sifat suatu larutan

\begin{tabular}{|c|c|c|}
\hline Kriteria & $\begin{array}{c}\sum \text { skor tiap } \\
\text { kriteria }\end{array}$ & $\begin{array}{c}\text { Persentase } \\
\text { kualitas }\end{array}$ \\
\hline 1 & 16,00 & 64,00 \\
\hline 2 & 18,00 & 72,00 \\
\hline
\end{tabular}

Berdasarkan Tabel 9, kriteria (2) Kepraktisan dalam penggunaan media audio visual dinilai lebih tinggi oleh reviewer karena dalam media audio visual tentang praktikum asam basa ini sudah memenuhi nilai kepraktisan dalam penggunaannya. Namun untuk kriteria (1) yaitu kemudahan mengoperasikan media audio visual dinilai lebih rendah dalam aspek ini, hal ini karena ada bagian media audio visual ini yang belum menunjukkan bagaimana penggunaan media audio visual ini dengan baik dimana penjelasan arah navigasi tiap-tiap pointer dalam media audio visual tersebut belum begitu jelas.
Aspek G yaitu aspek kegiatan siswa yang dijabarkan menjadi 3 kriteria. Aspek yang ketujuh ini memperoleh skor rata-rata sebesar 11,4 dengan kualitas baik sedangkan skor ratarata ideal yang diharapkan tercapai sebesar 15 . Jumlah skor masing-masing kriteria pada aspek ketujuh ini dapat dilihat pada Tabel 10.

Tabel 10. Jumlah skor kriteria media audio visual untuk aspek $G$ tentang penentuan sifat suatu larutan

\begin{tabular}{|c|c|c|}
\hline Kriteria & $\begin{array}{c}\sum \text { skor tiap } \\
\text { kriteria }\end{array}$ & $\begin{array}{c}\text { Persentase } \\
\text { kualitas }\end{array}$ \\
\hline 1 & 17,00 & 68,00 \\
\hline 2 & 19,00 & 76,00 \\
\hline 3 & 21,00 & 84,00 \\
\hline
\end{tabular}

Berdasarkan Tabel 10, kriteria (3) kesesuaian kegiatan siswa dengan materi pokok dalam Standar Isi dinilai lebih tinggi oleh reviewer karena media audio visual ini sudah disesuaikan dengan Standar Isi yang sesuai dengan materi pokok yang ada yaitu asam basa dimana hal ini mengacu pada Standar Kompetensi serta Kompetensi Dasar yang ada pada materi tersebut. Namun untuk kriteria (1) yaitu memberikan gambaran pengalaman kerja di laboratorium dinilai paling rendah dalam aspek ini karena dalam media audio visual ini hanya terbatas pada hal melihat dan mendengarkan saja namun tidak memberikan pengalaman psikomotorik langsung pada penggunanya.

Aspek yang terakhir yaitu aspek evaluasi belajar, dimana aspek ini dijabarkan menjadi 5 kriteria. Aspek yang terakhir ini memperoleh skor rata-rata sebesar 17,2 dengan kualitas baik sedangkan skor rata-rata ideal yang diharapkan tercapai sebesar 25. Jumlah skor masing-masing kriteria pada aspek terakhir ini dapat dilihat pada Tabel 11 .

Tabel 11. jumlah skor kriteria media audio visual untuk aspek $\mathrm{H}$ tentang penentuan sifat suatu larutan

\begin{tabular}{|c|c|c|}
\hline Kriteria & $\begin{array}{c}\text { N skor tiap } \\
\text { kriteria }\end{array}$ & $\begin{array}{c}\text { Persentase } \\
\text { kualitas }\end{array}$ \\
\hline 1 & 18,00 & 72,00 \\
\hline 2 & 18,00 & 72,00 \\
\hline 3 & 15,00 & 60,00 \\
\hline 4 & 17,00 & 68,00 \\
\hline 5 & 18,00 & 72,00 \\
\hline
\end{tabular}

Berdasarkan Tabel 11, kriteria (1) yaitu mengukur kemampuan kognitif siswa dinilai 
baik oleh reviewer karena dalam media audio ini memuat evaluasi-evaluasi yang mampu mengukur kemampuan kognitif siswa melalui dengan lembar kerja dan lembar evaluasi. Namun untuk kriteria (3) yaitu mengukur kemampuan psikomotorik siswa dinilai paling rendah karena dalam media audio visual ini siswa tidak langsung memerankan sebagai praktikan sehingga kriteria-kriteria dalam aspek psikomotorik peserta didik sulit untuk diukur.

\section{Kualitas media audio visual tentang penentuan $\mathrm{pH}$ suatu larutan}

Praktikum kedua ini memperoleh skor total rata-rata sebesar 136,4 dengan kualitas baik berdasarkan penilaian lima orang reviewer. Skor rata-rata ideal yang dicapai sebesar 180 . Skor yang diperoleh jika dinyatakan dalam persentase keidealan adalah $75,78 \%$. Sedangkan data skor rata-rata penilaian kualitas media audio visual tentang penentuan $\mathrm{pH}$ suatu larutan dapat dilihat pada Tabel 12 dan Gambar 3.

Tabel 12.Skor tiap aspek penilaian media audio visual tentang penentuan $\mathrm{pH}$ suatu larutan

\begin{tabular}{|c|c|c|c|}
\hline $\begin{array}{c}\text { Aspek } \\
\text { Penilaian }\end{array}$ & $\begin{array}{c}\text { Skor } \\
\text { Rata- } \\
\text { Rata }\end{array}$ & $\begin{array}{c}\text { Skor } \\
\text { Rata- } \\
\text { Rata } \\
\text { Ideal }\end{array}$ & $\begin{array}{c}\text { Persentase } \\
\text { Keidealan } \\
(\%)\end{array}$ \\
\hline A & $23(B)$ & 30 & 76,67 \\
\hline B & $12,8(\mathrm{SB})$ & 15 & 85,33 \\
\hline C & $23(B)$ & 30 & 76,67 \\
\hline D & $22,8(B)$ & 30 & 76,00 \\
\hline E & $19,4(B)$ & 25 & 77,60 \\
\hline F & $7,4(B)$ & 10 & 74,00 \\
\hline G & $11(B)$ & 15 & 73,33 \\
\hline H & $17(B)$ & 25 & 68,00 \\
\hline Jumlah & $136,4(B)$ & 180 & 75,78 \\
\hline
\end{tabular}

Aspek kebenaran, keluasan, dan kedalaman konsep dijabarkan menjadi 6 kriteria. Aspek yang pertama ini memperoleh skor rata-rata sebesar 23 dengan kualitas baik sedangkan skor rata-rata ideal yang diharapkan tercapai sebesar 30. Jumlah skor masingmasing kriteria pada aspek pertama ini dapat dilihat pada Tabel 13.

Tabel 13. Jumlah skor kriteria media audio visual untuk aspek $\mathrm{A}$ tentang penentuan $\mathrm{pH}$ suatu larutan

\begin{tabular}{|c|c|c|}
\hline Kriteria & $\underset{\text { kriteria }}{\sum \text { skor tiap }}$ & Persentase kualitas \\
\hline 1 & 19,00 & 76,00 \\
\hline 2 & 20,00 & 80,00 \\
\hline 3 & 19,00 & 76,00 \\
\hline 4 & 19,00 & 76,00 \\
\hline 5 & 19,00 & 76,00 \\
\hline 6 & 19,00 & 76,00 \\
\hline
\end{tabular}

Berdasarkan Tabel 13, kriteria (2) yaitu kelogisan dan sistematika uraian dinilai lebih tinggi oleh reviewer karena dalam media audio visual tentang praktikum asam basa ini sudah disesuaikan dengan standar isi dan tingkat berpikir siswa sehingga penyampaiannya sudah sistematis dan logis. Sedangkan kelima kriteria yang lain dinilai lebih rendah daripada kriteria yang kedua tadi, hal ini menunjukkan bahwa pada aspek yang pertama ini sudah sesuai dengan kebenaran, kedalaman dan keluasan konsep tentang asam basa.

Aspek B yaitu aspek kebahasaan dijabarkan menjadi 3 kriteria dan memperoleh skor rata-rata sebesar 12,8 dengan kualitas sangat baik sedangkan skor rata-rata ideal yang diharapkan tercapai sebesar 15. Jumlah skor masing-masing kriteria pada aspek kebahasaan yang digunakan ini dapat dilihat pada Tabel 14 .

Tabel 14. Jumlah skor kriteria media audio visual untuk aspek $\mathrm{B}$ tentang penentuan $\mathrm{pH}$ suatu larutan

\begin{tabular}{|c|c|c|}
\hline Kriteria & $\begin{array}{c}\sum \text { skor tiap } \\
\text { kriteria }\end{array}$ & Persentase kualitas \\
\hline 1 & 20,00 & 80,00 \\
\hline 2 & 22,00 & 88,00 \\
\hline 3 & 22,00 & 88,00 \\
\hline
\end{tabular}

Berdasarkan Tabel 14, kriteria (2) yaitu penggunaan bahasa yang tidak menimbulkan penafsiran ganda dan kriteria (3) penggunaan bahasa yang mudah dipahami atau komunikatif dinilai lebih tinggi oleh reviewer karena dalam media audio visual dalam topik ini telah menggunakan bahasa yang komunikatif serta tidak menimbulkan penafsiran ganda bagi para penggunanya. Namun untuk kriteria (1) penggunaan bahasa yang baku dinilai rendah karena ada beberapa kata-kata yang digunakan dalam media audio visual ini masih ada yang tidak baku.

Aspek C yaitu keterlaksanaan dijabarkan menjadi 6 kriteria. Aspek yang ketiga ini memperoleh skor rata-rata sebesar 23 dengan kualitas Baik (B), sedangkan skor rata- 
rata ideal yang diharapkan tercapai sebesar 30 . Jumlah skor masing-masing kriteria pada aspek ketiga ini dapat dilihat pada Tabel 15.

Tabel 15. Jumlah Skor Kriteria Media Audio Visual pada Aspek C pada Praktikum Penentuan $\mathrm{pH}$ suatu Larutan

\begin{tabular}{|c|c|c|}
\hline Kriteria & $\begin{array}{c}\sum \text { skor tiap } \\
\text { kriteria }\end{array}$ & Persentase kualitas \\
\hline 1 & 20,00 & 80,00 \\
\hline 2 & 19,00 & 76,00 \\
\hline 3 & 21,00 & 84,00 \\
\hline 4 & 19,00 & 76,00 \\
\hline 5 & 18,00 & 72,00 \\
\hline 6 & 18,00 & 72,00 \\
\hline
\end{tabular}

Berdasarkan Tabel 15, kriteria (3) yaitu kesesuaian jenis kegiatan yang digunakan dinilai paling tinggi oleh reviewer, hal ini karena dalam media audio visual tentang praktikum asam basa ini sudah disesuaikan dengan aspek kegiatan yang nantinya menunjang dalam proses pembelajaran. Namun untuk kriteria (5) yaitu membantu efektivitas belajar dan kriteria (6) yaitu penyajian materi secara menarik dinilai lebih rendah dari yang lainnya dalam aspek ini, hal ini karena media audio visual tentang praktikum asam basa ini ada bagian yang belum begitu menarik dalam penyampaian materi praktikumnya serta belum efektif apabila digunakan pada sekolah yang kurang fasilitasnya.

Aspek D yaitu aspek tampilan yang dijabarkan menjadi 6 kriteria. Aspek yang keempat ini memperoleh skor rata-rata sebesar 22,8 dengan kualitas Baik (B), sedangkan skor rata-rata ideal yang diharapkan tercapai sebesar 30. Jumlah skor masing-masing kriteria pada aspek keempat ini dapat dilihat pada Tabel 16.

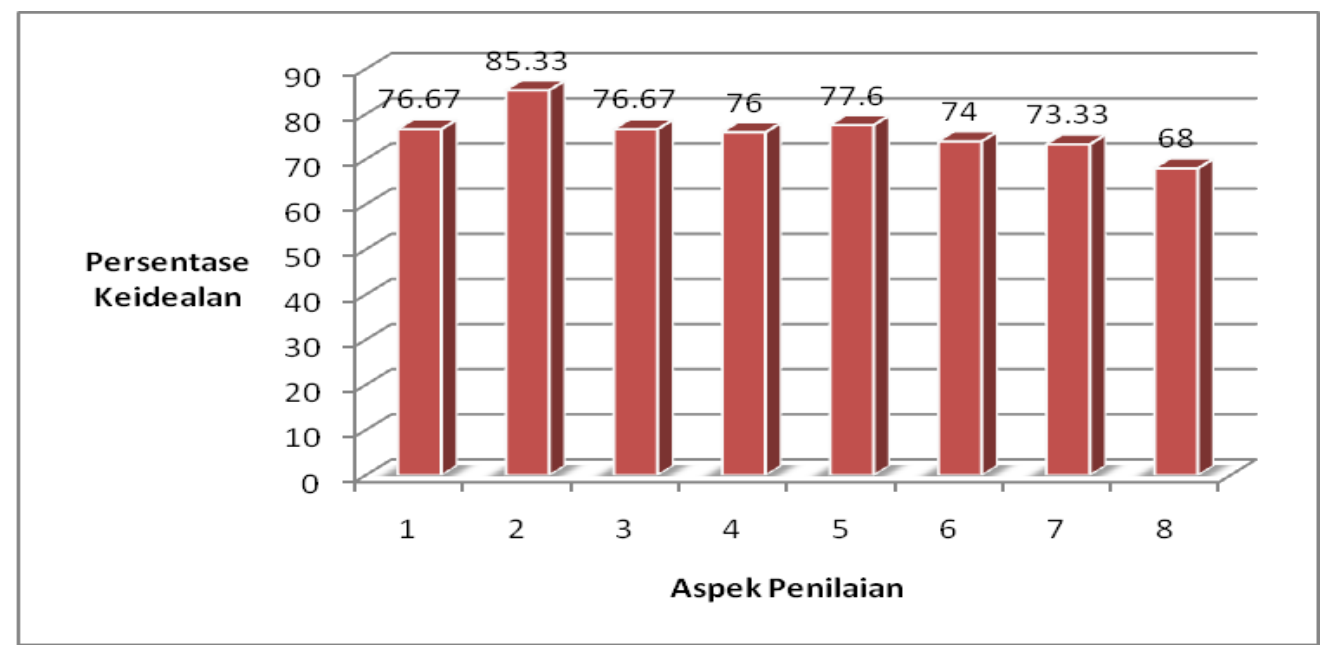

Gambar 3.Grafik skor tiap aspek penilaian media audio visual tentang penentuan $\mathrm{pH}$ suatu larutan

Tabel 16. Jumlah skor kriteria media audio visual untuk aspek $\mathrm{D}$ tentang penentuan $\mathrm{pH}$ suatu larutan

\begin{tabular}{|c|c|c|}
\hline Kriteria & $\begin{array}{c}\sum \text { skor tiap } \\
\text { kriteria }\end{array}$ & $\begin{array}{c}\text { Persentase } \\
\text { kualitas }\end{array}$ \\
\hline 1 & 19,00 & 76,00 \\
\hline 2 & 19,00 & 76,00 \\
\hline 3 & 20,00 & 80,00 \\
\hline 4 & 19,00 & 76,00 \\
\hline 5 & 18,00 & 72,00 \\
\hline 6 & 19,00 & 76,00 \\
\hline
\end{tabular}

Berdasarkan Tabel 16, kriteria (3) ukuran huruf dinilai lebih tinggi oleh reviewer karena media dalam topik ini sudah menggunakan huruf dengan ukuran yang proporsional. Namun untuk kriteria (5) yaitu kualitas pencahayaan dinilai lebih rendah dari kriteria yang lain dalam aspek ini karena video dalam media audio visual ini diambil tanpa pencahayaan yang cukup terang.

Aspek E yaitu aspek tampilan suara yang dijabarkan menjadi 5 kriteria. Aspek yang kelima ini memperoleh skor rata-rata sebesar 19,4 dengan kualitas baik sedangkan skor ratarata ideal yang diharapkan tercapai sebesar 25 . Jumlah skor masing-masing kriteria pada aspek kelima ini dapat dilihat pada Tabel 17. 
Tabel 17. Jumlah skor kriteria media audio visual untuk aspek $\mathrm{E}$ tentang penentuan $\mathrm{pH}$ suatu larutan

\begin{tabular}{|c|c|c|}
\hline Kriteria & $\begin{array}{c}\sum \text { skor tiap } \\
\text { kriteria }\end{array}$ & $\begin{array}{c}\text { Persentase } \\
\text { kualitas }\end{array}$ \\
\hline 1 & 17,00 & 68,00 \\
\hline 2 & 20,00 & 80,00 \\
\hline 3 & 20,00 & 80,00 \\
\hline 4 & 21,00 & 84,00 \\
\hline 5 & 19,00 & 86,00 \\
\hline
\end{tabular}

Berdasarkan Tabel 17, kriteria (4) yaitu kesesuaian suara dengan penunjukkan obyek dinilai lebih tinggi oleh reviewer karena komponen audion dalam media ini tidak melalui proses dubbing. Namun untuk kriteria (1) yaitu volume suara dinilai lebih rendah daripada kriteria yang lain dalam aspek ini karena dalam proses pengeditan video media ini ada pengurangan volume guna mengurangi vibrasi suara dari luar.

Aspek F yaitu aspek kemudahan penggunaan dijabarkan menjadi 2 kriteria. Aspek yang keenam ini memperoleh skor ratarata sebesar 7,4 dengan kualitas baik sedangkan skor rata-rata ideal yang diharapkan tercapai sebesar 10. Jumlah skor masing-masing kriteria pada aspek keenam ini dapat dilihat pada Tabel 18.

Tabel 18. Jumlah skor kriteria media audio visual untuk aspek $\mathrm{F}$ tentang penentuan $\mathrm{pH}$ suatu larutan

\begin{tabular}{|c|c|c|}
\hline Kriteria & $\begin{array}{c}\sum \text { skor tiap } \\
\text { kriteria }\end{array}$ & $\begin{array}{c}\text { Persentase } \\
\text { kualitas }\end{array}$ \\
\hline 1 & 18,00 & 72,00 \\
\hline 2 & 19,00 & 76,00 \\
\hline
\end{tabular}

Berdasarkan Tabel 18, kriteria (2) kepraktisan dalam penggunaan media audio visual dinilai lebih tinggi dari kriteria yang lain oleh reviewer karena media audio visual ini sudah memenuhi nilai kepraktisan dalam penggunaannya. Namun untuk kriteria (1) yaitu kemudahan pengoperasian media audio visual dinilai lebih rendah dalam aspek ini, hal ini karena ada bagian media audio visual ini yang belum menunjukkan bagaimana penggunaan media audio visual ini dengan baik dimana penjelasan arah navigasi tiap-tiap pointer dalam media audio visual tersebut belum begitu nampak.

Aspek $G$ yaitu aspek kegiatan siswa dijabarkan menjadi 3 kriteria. Aspek yang ketujuh ini memperoleh skor rata-rata sebesar 11 dengan kualitas baik sedangkan skor ratarata ideal yang diharapkan tercapai sebesar 15 . Jumlah skor masing-masing kriteria pada aspek ketujuh ini dapat dilihat pada Tabel 19.

Tabel 19. Jumlah skor kriteria media audio visual untuk aspek $\mathrm{G}$ tentang penentuan $\mathrm{pH}$ suatu larutan

\begin{tabular}{|c|c|c|}
\hline Kriteria & $\begin{array}{c}\sum \text { skor tiap } \\
\text { kriteria }\end{array}$ & $\begin{array}{c}\text { Persentase } \\
\text { kualitas }\end{array}$ \\
\hline 1 & 18,00 & 72,00 \\
\hline 2 & 18,00 & 72,00 \\
\hline 3 & 19,00 & 76,00 \\
\hline
\end{tabular}

Berdasarkan Tabel 19, kriteria (3) kesesuaian kegiatan siswa dengan materi pokok dalam Standar Isi dinilai lebih tinggi pada aspek ini oleh reviewer karena materi dalam media audio visual ini sudah disesuaikan dengan materi pokok yang ada yaitu asam basa dimana hal ini mengacu pada Standar Kompetensi serta Kompetensi Dasarnya. Namun untuk kriteria (1) yaitu memberikan gambaran pengalaman kerja di laboratorium dan kriteria (2) yaitu mendorong siswa menyimpulkan dinilai lebih rendah dalam aspek ini karena dalam media audio visual ini hanya terbatas pada hal melihat dan mendengarkan saja namun tidak memberikan pengalaman psikomotorik pada penggunanya serta belum adanya perintah kepada siswa untuk menyimpulkan.

Aspek yang terakhir yaitu aspek evaluasi belajar dijabarkan menjadi 5 kriteria. Aspek yang terakhir ini memperoleh skor ratarata sebesar 17 dengan kualitas baik skor ratarata ideal yang diharapkan tercapai sebesar 25 . Jumlah skor masing-masing kriteria pada aspek terakhir ini dapat dilihat pada Tabel 20.

Tabel 20. Jumlah skor kriteria media audio visual untuk aspek $\mathrm{H}$ tentang penentuan $\mathrm{pH}$ suatu larutan

\begin{tabular}{|c|c|c|}
\hline Kriteria & $\begin{array}{c}\sum \text { skor tiap } \\
\text { kriteria }\end{array}$ & $\begin{array}{c}\text { Persentase } \\
\text { kualitas }\end{array}$ \\
\hline 1 & 17,00 & 68,00 \\
\hline 2 & 17,00 & 68,00 \\
\hline 3 & 15,00 & 60,00 \\
\hline 4 & 18,00 & 72,00 \\
\hline 5 & 18,00 & 72,00 \\
\hline
\end{tabular}

Berdasarkan Tabel 20, kriteria (4) yaitu mengukur ketercapaian indikator keberhasilan yang dirumuskan dalam silabus dan kriteria (5) kesesuaian bobot evaluasi dinilai lebih baik 
oleh reviewer karena media audio visual ini sudah dapat mengukur indikator yang ada di silabus. Sedangkan untuk kriteria (3) yaitu mengukur kemampuan psikomotorik siswa dinilai paling rendah dalam aspek ini karena siswa tidak langsung memerankan sebagai praktikannya sehingga kriteria-kriteria dalam aspek psikomotorik peserta didik sulit untuk memenuhi skor maksimal.

Kedua topik yang disajikan dalam media hasil penelitian ini memenuhi nilai yang baik menurut reviewer. Menurut Urbanger \&Kometz (2014), media audio visual yang baik adalah media yang mampu menampilkan simulasi suatu proses dengan bahasa yang komunikatif. Menurut sediyani et al. (2017), media audio visual yang layak digunakan adalah yang komponen bahasa dan suaranya mampu menstimulasi pikiran, rasa, dan konsenstrasi siswa. Topik yang disajikan di media ini mendapatkan nilai sangat baik di aspek kebahasaan yang berarti memenuhi syarat tersebut.

Kelebihan dari media audio visual adalah media ini menampilkan gambar yang dinamis atau bergerak yang dikolaborasikan dengan suara yang bervariasi sehingga siswa menjadi tertarik mengikutinya (Santos \& Nishida, 1994). Semua gambar yang ditampilkan dalam media ini merupakan gambar yang bergerak diikuti dengan suara yang sinkron dengan gambar maupun inti pesan ilmiah yang disampaikan. Hal inilah yang menentukan aspek tampilan visual dan tampilan audio memenuhi kategori baik namun tidak bisa memenuhi kategori sangat baik karena peraga dalam video dan instrumen dalam pengambilan gambarannya belum memenuhi kriteria profesional.

Media audio visual yang efektif harus mengandung instruksi yang jelas, mudah digunakan, pesan yang disampaikan sesuai dengan standar kualitas ilmiah yang ditetapkan, mengandung komponen evaluasi sebagai sarana refleksi setelah audiens melihat videonya, dan kolaborasi desain grafis dan ahli informasi ilmiahnya (Tversky et al., 2006). Media ini juga memenuhi syarat yang ajukan oleh Tversky karena aspek yang berkaitan dengan validitas konsep, evaluasi siswa, dan kepraktisan penggunaan tergolong baik menurut reviewer. Selain karena mengikuti model baku dalam pengembangan produk penelitian, proses verifikasi oleh ahli media dan peer reviewer memberikan kontribusi yang besar dalam pengembangan media ini.
Hal menarik yang dibahas di artikel ini adalah aspek aktivitas siswa. Aspek ini juga mendapatkan penilaian baik namun kedua topik yang didemonstrasikan tidak bisa memberikan pengaruh maksimal pada kriteria psikomotor siswa. Dalam arti lain, media audio visual tetap tidak bisa menggantikan peran aktivitas nyata pembelajaran di dalam kelas maupun di laboratorium. Temuan ini mengkonfirmasi teori kognitif Mayer (...) dari pembelajaran berbasis multimedia yang menyebutkan bahwa siswa memiliki saluran kognitif yang terpisah dalam memroses informasi visual dan verbal, keterbatasan dalam proses di masing-masing saluran, dan untuk mendapatkan pengetahuan yang hakiki mereka harus memraktikkan secara langsung informasi yang mereka peroleh lalu menata informasi tersebut dalam skema pikiran dan selanjutnya mengintegrasikan informasi baru tersebut dengan pengetahuan yang telah mereka dapatkan sebelumnya (Mayer dalam Rosenthal \& Sanger, 2012).

\section{Simpulan dan Saran}

\section{Simpulan}

Penelitian ini berhasil mengembangkan media audio visual pada meteri lautan asam basa yang menampilkan topik bahasan tentang penentuan sifat keasaman suatu larutan dan penentuan $\mathrm{pH}$ suatu larutan. Media audio visual mendapatkan penilaian dengan kategori baik dengan skor rerata sebesar 130,80 dan persentase keidealan sebesar $72,67 \%$.

\section{Saran}

Media audio visual ini perlu diujicobakan ke siswa dalam pembelajaran dan diukur pengaruhnya terhadap hasil belajar, sikap, dan motivasi siswa. Pengembangan media pembelajaran sejenis perlu memperhatikan desain pengembangan yang lebih inovatif agar dapat memberikan pengaruh yang lebih besar pada sisi psikomotor siswa.

\section{E. Daftar Pustaka}

Akaygun, S. dan Jones, L.L. (2013). Researchbased design and development of a simulation of liquid-vapor equilibrium. Chem. Educ. Res. Pract., 14, 324 - 344. DOI: $10.1039 / \mathrm{c} 3 \mathrm{rp} 00002 \mathrm{~h}$.

Alessi, S.M., dan Trollip, S.R. (2001). Multimedia for learning: methods and development. New Jersey: Allyn and Bacon. 
Arikunto, S. (2002). Prosedur penelitian: suatu pendekatan praktik. Jakarta: Rineka Cipta.

Ashaver, D., dan Igyuve, S.M. (2013). The use of audio-visual materials in the teaching and learning processes in colleges of education in Benue State-Nigeria. IOSR Journal of Research \& Method in Education 1(6), 44-55.

Asmara, A.P. (2015). Pengembangan media pembelajaran berbasis audio visual tentang pembuatan koloid. Jurnal Ilmiah DIDAKTIKA, 15(2), 156 - 178.

Ben-Zvi, R., Eylon, B., \& Silberstein, J. (1987). Students' visualization of a chemical reaction. Education in Chemistry, 117120.

Blonder, R., Jonatan, M., Bar-Dov, Z., Benny, N., Rap, S., dan Sakhnini, S. (2013). Can You Tube it? Providing chemistry teachers with technological tools and enhancing their self-efficacy beliefs. Chem. Educ. Res. Pract., 14, 269 - 285.

Burewicz, A., dan Miranowicz, N. (2006). Effectiveness of multimedia laboratory instruction. Chem. Educ. Res. Pract., 7, $1-12$.

Calder, B.D. (2008). The selection and evaluation of audiovisual media for supporting learners with behavioural problems (LBP). Disertasi, tidak dipublikasikan. University of South Africa.

Cheng, M.M.W. (2017). Students' visualisation of chemical reactions - insights into the particle model and the atomic model. Chem. Educ. Res. Pract. DOI: 10.1039/c6rp00235h

Childs, P.E., dan Sheehan, M.A. (2007). What chemistry topics do students find difficult? Proceedings of the $2^{\text {nd }}$ European Variety in Chemistry Education. Prague: Charles University.

Coughian, M., Cronin, P., dan Ryan, F. (2007). Step'by-step guide to critiquing research. Part 1: quantitative research. British Journal of Nursing, 16(2), 658664.

Fry, H., Ketteridge, S., dan Marshall, S., (2009). A handbook for teaching and learning in higher education: enhancing academic practice. New York: Taylor \& Francis e-Library.

Johnstone, A.H. (2006). Chemical education research in Glasgow in perspective. Chemistry Education Research and Practice, 7(2), 49-63.

Mertler, C. A. (2001). Designing scoring rubrics for your classroom. Practical Assessment, Research \& Evaluation, $7(25)$.

Morgil, I., Secken, N., Yucel, A.S., Oskay, O.O., dan Temel, S. (2007). Relationship between shemistry education and media. Proceedings of the $23^{\text {rd }}$ International Conference on Chemistry Education, 66 - 69. Hradec Králové: University of Hradec Králové.

Nakhiekh, M.B. (1992). Why some students don't learn Chemistry. Journal of Chemistry Education, 69, 191 - 196.

Rosenthal, D.P., dan Sanger, M.J. (2012). Student misinterpretations and misconceptions based on their explanations of two computer animations of varying complexity depicting the same oxidation-reduction reaction. Chem. Educ. Res. Pract., 13, 471-483, DOI: 10.1039/c2rp20048a

Santos, I.V., dan Nishida, S. (1994). The effect of using audio visual aterials as a suppleent in teaching genenral chemistry. Diakses pada 23 Februari 2018 dari http://near.nara-edu.ac.jp/bitstream/10105/4420/1/CERT3_6583.pdf

Sediyani, T., Yufiarti, dan Hadi, E. (2017). Integration of Audio Visual Multimedia for Special Education Pre-Service Teachers' Self Reflections in Developing Teaching Competencies. Journal of Education and Practice, $8(6), 106-112$.

Sugiyono. (2009). Metode penelitian tindakan pendekatan kuantitatif, kualitatif, dan $R$ \& D. Bandung: Alfabeta.

Swank, R.C. (2011). The educational function of university library. Diakses pada 22 Februari 2018 dari http://www.ideals.illinois.edu/bitestream/handle/2142/5455 /librarytrend

Thomas, P.Y. (2010). Research Methodology and Design. Diakses pada 22 Februari 2018 dari http://uir.unisa.ac.za/bitstream/handle/10500/4245/05Chap\%20 4_Research\%20methodology\%20and\% 20design.pdf

Tversky, B., Agrawala, M., Heiser, J., Lee, P. U., Hanrahan, P., Phan, D., Stolte, C., dan Daniele, M. (2006) Cognitive design principles for automated 
generation of visualizations, in Allen G. (ed.), Applied spatial cognition: from research to cognitive technology. Mahwah, NJ: Erlbaum, 53-74.

Urbanger, M., dan Kometz, A., (2014). Research, theory and practice in chemistry didactics. Proceedings of the $23^{\text {rd }}$ International Conference on Chemistry Education, 182 - 192. Hradec Králové: University of Hradec Králové.

Wu, H., Krajcik, J.S., dan Soloway, E. (2000). Promoting Conceptual Understanding of Chemical Representations: Students' Use of a Visualization Tool in the Classroom. Proceeding of annual meeting of the National Association of Research in Science Teaching on April 28-May 12000 in New Orleans.

Zuljan, M.V., dan Vogrinc, J. (2010). Facilitating effective student learning through teacher research and innovation. Ljubljana: Faculty of Education. 